\title{
FIGURATIVE MEANING FOUND IN QUEEN'S ALBUM
}

\author{
Kadek Bagus Rusmana \\ Universitas Warmadewa \\ bagusrusmana18@gmail.com \\ I Nyoman Kardana \\ Universitas Warmadewa \\ ikardana@yahoo.com \\ I Gusti Ngurah Adi Rajistha \\ Universitas Warmadewa \\ rajistha@warmadewa.ac.id
}

\begin{abstract}
The phenomenon of miss interpretation and the mismatch of the desired meaning in a song's lyrics results in the wrong use of the song in an event. This study discusses the types of figurative meaning and their meaning related to each type. The data of this study were taken from the song lyrics of Queen's album. Data were collected by analyzing base on the theoretical concepts and the data were analyzed using the observation method. Data were obtained from listening and reading the song lyrics repeatedly. Based on the result of the analysis, it was found that there are nine types of figurative meaning that are used in twelve songs from Queen's Album. The figurative meaning that are used are metaphor, metonymy, overstatement/hyperbole, paradox, simile, symbol, synecdoche, euphemism, and idiom. Metaphor, metonymy, overstatement/hyperbole, simile, symbol, and idiom are the dominant type appeared the most with each 5 data, following by euphemism with 4 data, and the last are paradox and synecdoche with each 1 data. Thus, the total of all the data are 36 of the figurative meaning found in Queen's album. Metaphor, metonymy, overstatement/hyperbole, simile, symbol, and idiom are the dominant typed found in the song lyric because Queen's mostly uses substitutes and imagery in their songs.
\end{abstract}

Keywords: figurative meaning; types; Queen

\section{INTRODUCTION}

Language is a tool, system or container for communicating, either verbal, writing, spoken and even symbols used by humans, as members of socio-cultural groups to express their thoughts to others (Robins, 2020). Language has several social functions, including expression, play, imaginative, communication, identity expression, emotional release and to inform our feelings or meanings to others. It is because the needs of human communication are so various that is why the study of meaning is probably the most difficult part of the serious study of language.

Meaning has important part in communication and it also has an important role in learning about language because it will influence the information from the speaker to the listener. Meaning has two kinds, the first one is literal meaning and the second is figurative (non-literal) meaning (Larson, 1998).

Literal meaning is its basic or original meaning. It is often used when talking about facts or interesting information. Literal meaning contrasts with figurative meaning. For example: "The salt is salty." The literal meaning of the example is the taste of the salt is salty.

Figurative meaning is phrasing that has a hidden meaning behind some words and across the literal meaning to get the point (MasterClass, 2020). We can find figurative meaning in novels, advertisements, films, and also in the song lyrics. Figurative language is 
not only found in English, it is also found in other language such as Balinese language (Claria, Kardana, \& Rajistha, 2020; Satyawati, Kardana, \& Rajistha, 2020) The song lyrics are selected as the source of data because there are various song lyrics that can be found in our everyday life and song lyrics usually have a unique meaning.

Nowadays, human can speak up through song. Song also can be a something new for expressing human's feeling and song is an art. A song is a composition made up of lyrics and music, with the intent of the lyrics being sung, for the purpose of producing a proportionate feeling or emotion in relation to a particular matter (Guerra, 2015). Listening to songs, we can also feel comfortable and calm. Songs can have a lot of themes such as friendship, love, holiday, family and many more. Song consists of two elements such as lyric and music. Besides, people also can dig deeper meaning from the song as life motivation. Usually, a song uses non-literal lyric or figurative meaning to make a song more unique, various, interesting and different.

Queen's song lyrics are selected as the object of this research because of some reasons. The first reason is Queen's songs have an interesting music, and this band is very famous, so everyone must know how good their songs are. Second, those song lyrics contain a lot of figurative meanings. Third, these songs lyrics have never been analyzed by anyone else.

Queen is a British rock band founded in 1970 with the singer is Freddie Mercury, the guitarist is Brian May, the drummer is Roger Taylor and the bassist is John Deacon these are five members of Queen. The band was still active until 2009 even there are some members absence. The first time they were presented the show in 1970, at the City Hall of the City of Truro and the next show in Imperial College in the same year. Before they met John Deacon as a bassist, they tried out several test for the bassist like Doug Ewood Bogie, Mike Grose and Carry Mitchell. They met John Deacon in a bar and then recruited him to joined the band.in 1971 , for the first time he was appeared in the band. Freddie Mercury designed the logo of the Queen Band at the same year, he was inspired by zodiacal signs. He used zodiac signs of the members of the band, that is why the logo made of a crab for May who was Cancer, two lions for Deacon and Taylor who were Leo, and two fairies for Mercury who was Virgo (HistoryBiography, 2018).

In 1974, they played Seven Seas of Rhye and then it makes Queen appeared in the Top of the Pops. This news was broadcasted through on newspaper, radio and television, which highly promoted the song theme. In August 1975 , a masterpiece was made, this is the songs album entitled A Night at The Opera. As we all now know, this album was really magnificent. The entire package from this album is majestic, started from music, lyric, songs title, artwork is the whole pump. Their song contains many kinds of figurative meaning that is interesting to be analyzed (History-Biography, 2018).

Therefore, because Queen's album contains a lot of figurative meaning in their lyric, to understand them, we should learn how to interpret the figurative meaning. The application maybe in various ways, but the purpose is only to build a good impression on the listeners.

\section{METHOD}

The first step of this study was finding out the source of the data. The data of this research were taken from the Queen's songs that consist of figurative meaning, and the song lyrics were taken from lyricfind.com (LyricFind, n.d.). This band was a commercial success, topping charts in numerous countries including in the United States, Liverpool, Japan and the United Kingdom. The songs can be categorized in a Rock song and have a lot of types of figurative meanings because of unique and antimainstream artwork of writing. These are the reasons why these songs are very interesting to be analyzed.

In collecting the data, this research used the observation method. There were several steps in observing the data. The first step was listening to the Queen's repeatedly in order to identify figurative words. The second step was reading the lyrics. Then the next step was finding out the specific statements related to some types of figurative meaning that used in Queen's songs.

The collected data were analyzed through literary theory by Perrine (Perrine, 1987). Then the analysis of the data was presented in 
descriptive way supported by with some examples and explanations to support the examples.

\section{DISCUSSION}

All the data were collected from the Queen's album and the lyrics were classified based on the problems discussed. The data analysis of figurative meaning is based on the theoretical concepts which have been explained in the previous chapter. Before talking about types and the real meanings of figurative meaning, the Queen's album needs to be explained. Queen's album called A Night at Opera is the one of masterpiece in music history. There are twelve songs in the album as the data, they are "Death on Two Legs", "Lazing on A Sunday Afternoon", "I'm in Love with My Car", "You're My Best Friend”, “'39”, "Sweet Lady", "Seaside Rendezvous", "The Prophet's Song", "Love of My Life", "Good Company", "Bohemian Rhapsody", "God Save The Queen". After reading the lyrics repeatedly and carefully, nine types of figurative forms are found in these song lyrics, they are metaphor, metonymy, overstatement/hyperbole, paradox, simile, symbol, synecdoche, euphemism, and idiom.

Data 1. Metaphor

\begin{tabular}{|c|c|c|}
\hline & Figurative Sentence & Literal Meaning \\
\hline 1 & $\begin{array}{l}\text { You're just an old } \\
\text { arrow boy (Death on } \\
\text { Two Legs - line 14). }\end{array}$ & $\begin{array}{l}\text { The way a manager } \\
\text { treats an artist, } \\
\text { when the artist gets } \\
\text { older and cannot } \\
\text { keep up with the } \\
\text { times, they will } \\
\text { leave him and } \\
\text { replace him with a } \\
\text { new one. }\end{array}$ \\
\hline 2 & $\begin{array}{l}\text { You're a sewer rat } \\
\text { decaying in a } \\
\text { cesspool of pride } \\
\text { (Death on Two Legs - } \\
\text { line 34). }\end{array}$ & $\begin{array}{l}\text { The meaning about } \\
\text { this lyric is how an } \\
\text { arrogant and greedy } \\
\text { person died. }\end{array}$ \\
\hline 3 & $\begin{array}{l}\text { You're my sunshine } \\
\text { and I want you to } \\
\text { know (You're My } \\
\text { Best Friend-line 08). }\end{array}$ & $\begin{array}{l}\text { The meaning of this } \\
\text { lyric is the singer } \\
\text { feels very happy } \\
\text { has a best friend in } \\
\text { his life. }\end{array}$ \\
\hline 4 & $\begin{array}{l}\text { Oh, you're my best } \\
\text { friend (You're My } \\
\text { Best Friend - line 11). }\end{array}$ & $\begin{array}{l}\text { The meaning of this } \\
\text { lyric is the singer } \\
\text { feels very happy } \\
\text { because he has }\end{array}$ \\
\hline
\end{tabular}

\begin{tabular}{ccc}
\hline & $\begin{array}{l}\text { someone who } \\
\text { always listens and } \\
\text { understands him. }\end{array}$ \\
\hline $5 \quad \begin{array}{c}\text { For the earth is old } \\
\text { and grey, little } \\
\text { darling, we'll away } \\
\text { ('39- line 19). }\end{array}$ & $\begin{array}{c}\text { The meaning of the } \\
\text { lyric is world is full } \\
\text { of downgrade } \\
\end{array}$ & music that is now \\
& very different from \\
& the amazing 60s, \\
& 70 s and 80s music. \\
\hline
\end{tabular}

- You're my sunshine and I want you to know (You're My Best Friend - line 08).

"You're my sunshine and I want you to know" is one of the song lyrics of Queen's song entitled "You're My Best Friend" found in line 08. In this lyric, the word 'you' is the first idea as a topic, and the phrase 'my sunshine' are the second idea as an image. The phrase 'my sunshine' refers to someone who can cheer up the singer for a long time. The singer explains about someone who has a relationship with him. The meaning of this lyric is the singer feels very happy has a best friend in his life. That is why she calls his friend with 'my sunshine' and the singer want to his friend know about that feeling. This lyric directly refers to one thing by mentioning another. It provides clarity or identify hidden similarities between two ideas.

Data 2. Metonymy

\begin{tabular}{|c|c|c|}
\hline & Figurative Sentence & Literal Meaning \\
\hline 1 & $\begin{array}{l}\text { Screw my brain till it } \\
\text { hurts (Death on Two } \\
\text { Legs - line } 03 \text { ). }\end{array}$ & $\begin{array}{l}\text { The singer was very } \\
\text { concerned about a } \\
\text { very serious } \\
\text { problem, so that it } \\
\text { makes his mind } \\
\text { confused and } \\
\text { becomes a burden } \\
\text { on the mind. The } \\
\text { problem makes his } \\
\text { mind eroded and } \\
\text { caused pain. }\end{array}$ \\
\hline 2 & $\begin{array}{l}\text { The machine of a } \\
\text { dream, such a clean } \\
\text { machine (I'm in Love } \\
\text { with my car - line 02). }\end{array}$ & $\begin{array}{l}\text { The singer dream } \\
\text { about to get a new } \\
\text { car. The singer } \\
\text { always dreaming } \\
\text { about that car. He } \\
\text { really likes that car. }\end{array}$ \\
\hline 3 & $\begin{array}{l}\text { Write your letters in } \\
\text { the sand (' } 39 \text { - line } \\
\text { 12). }\end{array}$ & $\begin{array}{l}\text { The singer really } \\
\text { wants to tell people } \\
\text { in the future about } \\
\text { music taste in his } \\
\text { era is really }\end{array}$ \\
\hline
\end{tabular}




\begin{tabular}{lll}
\hline & & $\begin{array}{l}\text { amazing, so he } \\
\text { wants people in the } \\
\text { future can } \\
\text { perpetuate that } \\
\text { music in their era. }\end{array}$ \\
\hline $4 \quad \begin{array}{l}\text { Thought their hearts } \\
\text { so heavily weigh ('39 } \\
\text { - line 18). }\end{array}$ & $\begin{array}{l}\text { The singer wants to } \\
\text { tell to everyone that } \\
\text { he really } \\
\text { disappointed with } \\
\text { the taste of music in } \\
\text { the future. }\end{array}$ \\
\hline 5 Your mother's eyes, & $\begin{array}{l}\text { The singer wants to } \\
\text { explains about the } \\
\text { ancestors crying see } \\
\text { their successors. }\end{array}$ \\
\hline
\end{tabular}

- Screw my brain till it hurts (Death on Two Legs - line 03).

"screw my brain till it hurts" is one of the song lyrics of Queen's song entitled "Death on Two Legs" found in line 03. This lyric shows metonymy. The phrase 'screw my brain' refers to mind burden. In this song, the singer shows his anger and depression. The phrase 'screw my brain' explains about his emotional response to the problems from his manager did. It is clear that the lyric contains figurative forms of metonymy which an object or concept is referred to not by its own name, but instead by the name of something closely associated with it. The literal meaning of the lyrics is that he was very concerned about a very serious problem, so that it makes his mind confused and becomes a burden on the mind. The problem makes his mind eroded and caused pain.

Data 3. Overstatement/Hyperbole

\begin{tabular}{|c|c|c|}
\hline & Figurative Sentence & Literal Meaning \\
\hline 1 & $\begin{array}{l}\text { Ooh, you make me } \\
\text { live (You're My Best } \\
\text { Friend - line 01). }\end{array}$ & $\begin{array}{l}\text { The literal meaning } \\
\text { of the lyric is the } \\
\text { singer just wants to } \\
\text { say if he is very } \\
\text { happy to has a } \\
\text { someone special in } \\
\text { his life. }\end{array}$ \\
\hline 2 & $\begin{array}{l}\text { Whatever this world } \\
\text { can give to me } \\
\text { (You're My Best } \\
\text { Friend - line 02). }\end{array}$ & $\begin{array}{l}\text { The literal meaning } \\
\text { of the lyric is that } \\
\text { the singer how } \\
\text { happy he is can } \\
\text { meet someone } \\
\text { special in his life } \\
\text { that can keep up } \\
\text { with him. }\end{array}$ \\
\hline
\end{tabular}

3 It's you you're all I The literal meaning see (You're My Best of the lyric is that Friend-line 03). the singer very happy has a best friend in his life. Someone who can he rely on in his life.

4 Oh, you're the best The literal meaning friend that I ever had of the lyrics is the (You're My Best singer shows how Friend - line 06). happy he has a best friend in his life.

5 The Sweetest sight The literal meaning ever seen ('39 - line of this lyric is the 04). singer just wants to say he saw a very beautiful scenery and he likes that.

- It's you you're all I see (You're My Best Friend - line 03).

The lyric "it's you you're all I see" is some lyric from Queen's song entitled "You're My Best Friend". The lyrics are found in line 03. The sentence 'you're all I see' is very clear that this includes overstatement/hyperbole that contains statements that deliberately exaggerate. The lyrics mean the singer only saw his best friend in his life. The singer expresses his happiness with that song lyric. The expression about how happy he is, because he has a best friend in his life who always there for him in every situation. The literal meaning of the lyric is that the singer very happy has a best friend in his life. Someone who can he rely on in his life. The singer and his best friend always together in every situation.

Data 4. Paradox

\begin{tabular}{lll}
\hline Figurative Sentence & \multicolumn{1}{c}{ Literal Meaning } \\
\hline 1 So you think you can & The literal meaning \\
love me and leave me & of the lyric is, the \\
to die (Bohemian & singer wants to \\
Rhapsody - line 49) & $\begin{array}{l}\text { explains about what } \\
\text { he feels to the } \\
\end{array}$ & woman he loves. \\
\hline
\end{tabular}

- So you think you can love me and leave me to die (Bohemian Rhapsody - line 49).

From the lyric "So you think you can love me and leave me to die" is one of song lyrics of 
Queen's song entitled "Bohemian Rhapsody" found in line 49. The lyric it is seemingly absurd statement or proposition, it is clear the lyrics contain a figurative meaning od paradox. The phrase 'love me' and the sentence 'leave me to die' in this lyric looks weird and absurd. When you love someone, you will never ever leave them. The literal meaning of the lyric is, the singer wants to explains about what he feels to the woman he loves. The woman he loved, played his feeling. In this song, the singer is suffering from a very serious illness. He was on the verge of death from his illness. The woman he loved left him because of his dying condition. The singer really sad. He is dying and the woman his loved left him. The singer wants to convey a message to all fans in the world. Love your partner in a happy state even though it is difficult. Love your partner with all your heart.

Data 5. Simile

\begin{tabular}{|c|c|c|}
\hline & Figurative Sentence & Literal Meaning \\
\hline 1 & $\begin{array}{l}\text { You suck my blood } \\
\text { like a leech (Death on } \\
\text { Two Legs - line 01). }\end{array}$ & $\begin{array}{l}\text { A person who } \\
\text { always enslaved, } \\
\text { and always took } \\
\text { advantage of the } \\
\text { singer. }\end{array}$ \\
\hline 2 & $\begin{array}{l}\text { You talk like a big } \\
\text { business tycoon } \\
\text { (Death on Two Legs - } \\
\text { line 24). }\end{array}$ & $\begin{array}{l}\text { The singer wants to } \\
\text { explains about his } \\
\text { manager } \\
\text { always } \\
\text { nonsense. }\end{array}$ \\
\hline 3 & $\begin{array}{l}\text { You call me up and } \\
\text { treat me like a dog } \\
\text { (Sweet Lady }- \text { line } \\
\text { 02). }\end{array}$ & $\begin{array}{l}\text { The literal meaning } \\
\text { of the lyric is the } \\
\text { singer was not } \\
\text { served well. His } \\
\text { girlfriend always } \\
\text { disappoints and } \\
\text { makes him sad. }\end{array}$ \\
\hline 4 & $\begin{array}{l}\text { You call me sweet like } \\
\text { I'm some kind of } \\
\text { cheese (Sweet Lady - } \\
\text { line 14). }\end{array}$ & $\begin{array}{l}\text { The singer wants to } \\
\text { explains that the } \\
\text { woman's face is } \\
\text { like a piece of a } \\
\text { cheese which is } \\
\text { very tasty and } \\
\text { sweet. }\end{array}$ \\
\hline 5 & $\begin{array}{l}\text { Return like the white } \\
\text { dove (Prophet's Song } \\
\text { - line 23). }\end{array}$ & $\begin{array}{l}\text { We have to be good } \\
\text { and get back to } \\
\text { God's way. }\end{array}$ \\
\hline
\end{tabular}

- You suck my blood like a leech (Death on Two Legs - line 01).
The lyric "you suck my blood like a leech" is one of song lyrics of Queen's song entitled "Death on Two Legs" found in line 01. The sentence 'you suck my blood' and the word 'leech' are compared and they show similarities between two different things. These lyrics also use the word 'like' to compare the sentence 'you suck my blood' and the word 'leech', which it is clear figurative meaning of simile. The sentence 'you suck my blood' refers to the greedy manager who always pressured him. Leech is an animal that shaped like a worm and like suck blood. In this case, the greedy manager compared with a leech. The literal meaning of this lyric is, the singer wants to explains about his manager. His manager always put pressure on him and hire him without a break. He was always enslaved, and the manager always took advantage of him. The manager like a 'leech' in his life.

Data 6. Symbol

\begin{tabular}{|c|c|c|}
\hline & Figurative Sentence & Literal Meaning \\
\hline 1 & $\begin{array}{l}\text { For many a lonely day } \\
\text { sailed across the milky } \\
\text { seas ('39- line } 08) \text {. }\end{array}$ & $\begin{array}{l}\text { The literal meaning } \\
\text { of the lyric is the } \\
\text { singer wants to } \\
\text { explains about a } \\
\text { sailor who sailed in } \\
\text { the night in the } \\
\text { open seas. }\end{array}$ \\
\hline 2 & $\begin{array}{l}\text { And ice cold hearts of } \\
\text { charity bare } \\
\text { (Prophet's Song - line } \\
\text { 09). }\end{array}$ & $\begin{array}{l}\text { The literal meaning } \\
\text { of the lyric is that a } \\
\text { man who felt sad } \\
\text { for a very long time. } \\
\text { This makes him } \\
\text { become a 'ice cold } \\
\text { heart' and his give } \\
\text { his true heart to } \\
\text { someone else. His } \\
\text { heart completely } \\
\text { died and froze. }\end{array}$ \\
\hline 3 & $\begin{array}{l}\text { Oh, oh, children of the } \\
\text { land (Prophet's Song } \\
\text { - line 19). }\end{array}$ & $\begin{array}{l}\text { The singer wants to } \\
\text { explains about the } \\
\text { message that God } \\
\text { delivered to all } \\
\text { human in the world. }\end{array}$ \\
\hline 4 & $\begin{array}{l}\text { These kings of the } \\
\text { beasts now counting } \\
\text { their days (Prophet's } \\
\text { Song - line 27). }\end{array}$ & $\begin{array}{l}\text { The literal meaning } \\
\text { of the lyric is kings } \\
\text { of demons in the } \\
\text { hell waiting for } \\
\text { their day to carry } \\
\text { out their duties. }\end{array}$ \\
\hline 5 & $\begin{array}{l}\text { Meantime I ask you to } \\
\text { be my valentine }\end{array}$ & $\begin{array}{l}\text { The literal meaning } \\
\text { of the lyric is about } \\
\text { a man who falling }\end{array}$ \\
\hline
\end{tabular}




\begin{tabular}{ll}
\hline (Seaside Rendezvous & in love with a \\
- line 24). & gorgeous woman. \\
\hline
\end{tabular}

- Oh, oh, children of the land (Prophet's Song - line 19).

"oh, oh, children of the land" is one lyric of Queen's song entitled "Prophet's Song". This lyric found in line 19. The phrase "children of the land' means all human in this earth. The singer uses representing object in the lyric, which it is clear a figurative meaning of symbol. The singer wants to explains about the message that God delivered to all human in the world. All 'children of the land' must be aware of that. This is a very important message. God wants to warn us that the end is near and all human in the world must immediately repent and return to God's way. The lyrics of the song very touching our heart. It contains messages that are very important to all of us. The singer added with the addition of figurative meaning that make us aware of the great power of God.

Data 7. Synecdoche

\begin{tabular}{lll}
\hline Figurative Sentence & Literal Meaning \\
\hline 1 All your letters in the & The literal meaning \\
sand cannot heal me & of the lyric is, there \\
like your hand ('39- & is a message from \\
line 29). & the past people that \\
& conveyed through \\
& the media which is \\
& very strong and \\
& enduring. \\
\hline
\end{tabular}

- All your letters in the sand cannot heal me like your hand ('39 - line 29).

In the data above, the lyric "all your letters in the sand cannot heal me like your hand" is the one of the song lyrics from Queen's song entitled " "39". The lyric found in line 29. The word 'hand' refers to the human body. The lyric contains of a figurative meaning of synecdoche, it is because the word 'hand' in the lyric associate or replace a whole part. The singer wants to explains that nothing can replace the loving touch of the body in this world. The literal meaning of the lyric is, there is a message from the past people that conveyed through the media which is very strong and enduring. The message is aimed at the people of the future. But all those messages are very useless in the future. They are meaningless without the physical and bodily touches of the people of the past. The lyric it is about how important body touch is to heal or convey a message. The singer wants to explains to the all fans in the world that we must appreciated every moment in our life. Because once it is gone, nothing can make it come back again in this life.

Data 8. Euphemism

\begin{tabular}{|c|c|c|}
\hline & Figurative Sentence & Literal Meaning \\
\hline 1 & $\begin{array}{l}\text { Then make yourself } \\
\text { null and void (Death } \\
\text { on Two Legs - line } \\
\text { 36). }\end{array}$ & $\begin{array}{l}\text { The literal meaning } \\
\text { of the lyric is, the } \\
\text { singer desperately } \\
\text { wanted his manager } \\
\text { to die needlessly, } \\
\text { hated, unemployed } \\
\text { and nobody knew. }\end{array}$ \\
\hline 2 & $\begin{array}{l}\text { With your narrow } \\
\text { minded } \quad \text { cronies } \\
\text { (Death on Two Legs - } \\
\text { line 07) }\end{array}$ & $\begin{array}{l}\text { The literal meaning } \\
\text { of the lyric is, the } \\
\text { singer wants to } \\
\text { explain about his } \\
\text { manager who really } \\
\text { 'stupid'. }\end{array}$ \\
\hline 3 & $\begin{array}{l}\text { You've never had a } \\
\text { heart of your own } \\
\text { (Death on Two Legs - } \\
\text { line 12) }\end{array}$ & $\begin{array}{l}\text { The literal meaning } \\
\text { of the lyric is, the } \\
\text { singer wants to } \\
\text { explains about his } \\
\text { manager who looks } \\
\text { like a demon. He } \\
\text { really likes to talk } \\
\text { nonsense. }\end{array}$ \\
\hline 4 & $\begin{array}{l}\text { Death on two legs } \\
\text { (Death on Two Legs - } \\
\text { line 09) }\end{array}$ & $\begin{array}{l}\text { The singer wants to } \\
\text { explains about the } \\
\text { condition about his } \\
\text { manager who died } \\
\text { in very bad } \\
\text { condition. }\end{array}$ \\
\hline
\end{tabular}

- Then make yourself null and void (Death on Two Legs - line 36).

The lyric "then make yourself null and void" is one of the lyrics from Queen's song entitled "Death on Two Legs". The lyric found in line 36. The singer uses a polite expression in the lyric, which it is very clear a figurative meaning of euphemism. The sentence "null and void' refers to useless and died. The sentence 'useless and died' is too vulgar to say, that is why it is euphemistically used by saying 'null and void'. The word 'yourself' refers to the singer's manager. The literal meaning of the lyric is, the singer desperately wanted his manager to die needlessly, hated, unemployed 
and nobody knew. It will make the singer feel really good. It is all because what his manager did to him was very mean and costly to him. The singer just wants to give the results that his manager has been doing all his life. This singer really uses very precise words.

Data 9. Idioms

\begin{tabular}{|c|c|c|}
\hline & Figurative Sentence & Literal Meaning \\
\hline 1 & $\begin{array}{l}\text { You eat me up (Sweet } \\
\text { Lady - line 16). }\end{array}$ & $\begin{array}{l}\text { The lady always } \\
\text { makes him happy, } \\
\text { smile and in a good } \\
\text { mood. He likes how } \\
\text { the lady treated } \\
\text { him. }\end{array}$ \\
\hline 2 & $\begin{array}{l}\text { You hold me down } \\
\text { (Sweet Lady - line } \\
\text { 17). }\end{array}$ & $\begin{array}{l}\text { The lady who } \\
\text { makes him feel sad } \\
\text { and 'down'. The } \\
\text { lady he met always } \\
\text { make him upset. }\end{array}$ \\
\hline 3 & $\begin{array}{l}\text { I feel like dancing in } \\
\text { the rain (Seaside } \\
\text { Rendezvous }- \text { line } \\
\text { 15). }\end{array}$ & $\begin{array}{l}\text { This lyric is about a } \\
\text { man who really } \\
\text { enjoy his life. His } \\
\text { life happily because } \\
\text { he never let a bad } \\
\text { thing makes him } \\
\text { sad }\end{array}$ \\
\hline 4 & $\begin{array}{l}\text { For those who hear } \\
\text { and mark my words } \\
\text { (Prophet's Song-line } \\
\text { 34). }\end{array}$ & $\begin{array}{l}\text { The literal meaning } \\
\text { of the lyric is about } \\
\text { God's messages are } \\
\text { conveyed through } \\
\text { the seer. }\end{array}$ \\
\hline 5 & $\begin{array}{l}\text { Too late, my time has } \\
\text { come (Bohemian } \\
\text { Rhapsody - line 20). }\end{array}$ & $\begin{array}{l}\text { A disease that he } \\
\text { had suffered for a } \\
\text { long time, and it } \\
\text { was his 'time has } \\
\text { come' for the singer } \\
\text { to return to God's } \\
\text { grace. }\end{array}$ \\
\hline
\end{tabular}

- Too late, my time has come (Bohemian Rhapsody - line 20).

The sentence "Too late, my time has come" is one of the lyrics from Queen's song entitled "Bohemian Rhapsody". This lyric found in line 20. The phrase 'time has come' means this is a good time to do something or for something to happen. A person or animal has reached the end of its life. The lyric contains figurative meaning of idiom. It is because the lyric uses words which have a meaning that cannot be subtracted from individual words. These lyrics are about the singer's illness. A disease that he had suffered for a long time, and it was his 'time has come' for the singer to return to God's grace. This disease he got because he is a bisexual and he has a sex with a man. It is too late for him to confess anything to his mom. He wants his mom live happily. The singer is really a legendary singer, he died in peace and left many works of legends. All of his works are still remembered by everyone in the world today. A message that can we learn from this lyric is we must always be kind and honest to those who we love. This is because we don't know when and where God will end our lives in this world, because we are only God's servants.

\section{CONCLUSION}

Figurative meaning is phrasing that goes beyond the literal meaning of words to get a message or point across. Furthermore, the conclusion of the discussion is based on the analysis in the previous chapter. From the analysis, it can be concluded that there are some types of figurative meaning that are found in the song lyrics. The types of figurative meaning that are found in the song lyrics are metaphor, metonymy, overstatement/hyperbole, paradox, simile, symbol, synecdoche, euphemism, and idiom. Each kind of those figurative meaning has certain purposes. Metaphor is used as an implied comparison between two different things. Metonymy is used to compare something that involving association. Overstatement/hyperbole is used to exaggerate the condition of the story within the song. Paradox is the juxtaposition of a set of seemingly contradictory concepts that reveal a hidden and/or unexpected truth. Simile is used to makes a comparison, showing similarities between two different things that draw resemblance with the help of the words "like" or "as". Symbol can be representing through continued use and common understanding a simple object or a complex pattern of association or ideas. Synecdoche is the use of the part for the whole of something or an object. Euphemism is used to avoid an offensive expression, or one that is socially unacceptable, or one that is unpleasant. And idiom is a phrase that people say that is commonly accepted as having a different meaning that the individual words may lead you to believe. Based on the analysis, metaphor, metonymy, overstatement/hyperbole, simile, symbol, and 
idiom are the dominant type that appeared the most with each 5 data, following by euphemism with 4 data, and the last are paradox and synecdoche with each 1 data. Thus, the total of all the data are 36 of the figurative meaning found in Queen's album. After analyzing the data, the real meanings of figurative meaning found in Queen's song lyrics are mostly about love and sickness. It can be shown in most of the lyrics which tell about behavior of someone who is fall in love and share some loves. In other hand, the lyric shown about disease, plague, religion and death.

In addition, Figurative meaning is very interesting point to be observed. That's why in this opportunity, the writer would like to give suggestion is to direct the further researcher on the same topic. To the student and readers in the same major who interested in analyzing figurative meaning, this research leads the students and readers to find out figurative meaning and the use of them in the song lyrics. First, before doing an analysis, it is better for further researchers if they find out of the problems that will be observed first. The researchers should understand about figurative meaning and prepare the theoretical books and data source as well. It will make examining the figurative meaning easier. Second, in this analysis, there are some types that cannot be found in the source of data. Third, this suggestion is for lecturers. It is important for the lecturer to give more attention in teaching the theory of figurative meaning. The result of this research show that the student needs more hours to learn about figurative meaning including the definitions, the functions, and the identification practice. Fourth, for further study, it is suggested to find out the students' difficulties in recognizing certain types of figurative meaning and the reason why such type of figurative meaning is difficult for them. Furthermore, we should learn in understanding and appreciating literary works because by appreciating them, it grows a good attitude.

\section{REFERENCES}

Claria, D. A. K., Kardana, I. N., \& Rajistha, I. G. N. A. (2020). Modernization on balinese proverbs to express someone's emotion. International Journal of Psychosocial Rehabilitation, 24(8). https://doi.org/10.37200/IJPR/V24I8/PR2 80483

Guerra, J. (2015). What is A Song, Anyway? Retrieved January 4, 2021, from https://www.jonguerramusic.com/blog/20 15/5/6/what-is-a-song-anyway

History-Biography. (2018). Queen History. Retrieved January 4, 2021, from https://history-biography.com/history-ofqueen/

Larson, M. L. (1998). Meaning-Based Translation, A Guide to Across-Language Equivalence. New York: University Press of America.

LyricFind. (n.d.). Lyric Find. Retrieved January 4, 2021, from https://www.lyricfind.com/

MasterClass. (2020). Writing 101: What is Figurative Language? Learn about 10 types of Figurative Language with Examples. Retrieved January 4, 2021, from

https://www.masterclass.com/articles/writ ing-101-what-is-figurative-languagelearn-about-10-types-of-figurativelanguage-with-examples\#quiz-0

Perrine, L. (1987). Sound and Sense: An Introduction of Poetry (Seventh Ed). New York: Southern Methodist University.

Robins, R. H. (2020). Language. Retrieved January 4, 2021, from https://www.britannica.com/topic/languag e

Satyawati, M. S., Kardana, I. N., \& Rajistha, I. G. N. A. (2020). Figurative language in Balinese based on social praxis analysis. Talent Development \& Excellence, 12(2). 